\title{
Optimization of Biodiesel production from mixed oil (Karanja \& Dairy waste Scum oil) using Homogeneous Catalyst.
}

\author{
K V Yathish ${ }^{1}$, Dr. R Suresh ${ }^{2}$, Amruth. $E^{3}$ \\ 1. Scientific Assistant, Bio fuel I\&D Centre, Siddaganga Institute of Technology,Tumkur, Karnataka, India. \\ 2. Associate Professor, Mechanical Department, Siddaganga Institute of Technology,Tumkur, Karnataka, India. \\ 3. M.Tech (TPE), Mechanical Department, Siddaganga Institute of Technology, Tumkur, Karnataka, India.
}

\begin{abstract}
In this study, crude mixed oil was used as feedstock for biodiesel production by Homogeneous Catalyst. The reaction in the presence of $\mathrm{KOH}$ as catalyst was carried out to investigate the optimum conditions and study the effect of variables on the reaction. The variables included methanol to oil molar ratios, catalyst concentrations, reaction temperature and reaction times. Gas chromatography was used to determine the fatty acid composition of mixed oil. The optimum conditions for mixed oil biodiesel production were a catalyst concentration of $1.0 \% \mathrm{w} / \mathrm{w}$ of oil, a reaction temperature of $70^{\circ} \mathrm{C}$, a reaction time of 30minutes $6: 1$ methanol to oil molar ratio at 400rpm. The methyl ester content under these optimum conditions was $95.10 \%$, and all the measured properties of mixed oil biodiesel met the ASTM standards.
\end{abstract}

Keywords: Mixed oil, Homogeneous Catalyst, Biodiesel, ASTM standards.

\section{Introduction}

Alternative fuel derived from vegetable oil and animal fat have increasingly important due to decreasing petroleum resources and increase in pollution problems. Biodiesel is a cleaner fuel than petroleum diesel and an exact substitute for existing compression engines [1]. Scarcity of fossil fuel increases the searching of new biomass to trap renewable energy sources more attractive. Currently biodiesel is prepared from oil like soybean, canola, palm, sunflower etc. throughout the world [2,3]. It is now believed that the world food crisis will occur as the result of using food crops for producing biodiesel [4]. This lead to search for excavation of biodiesel feed stocks from unconventional, nonedible oil and fats like, waste grease, waste cooking oil, waste tallow, jatropha seed oil, tobacco seed oil, rubber seed oil, polanga seed oil etc. Biodiesel is generally reported as being more costly than conventional diesel fuel. The cost of raw materials accounts for $75-85 \%$ of the production cost of biodiesel $[5,6]$. The higher price of biodiesel made researchers to look for newer ways to reduce cost to make newer biodiesel competitive. The present analysis revels that biodiesel from mixed oil (Scum and Karanjia oil) is a suitable alternative for petroleum diesel.

\subsection{Scum oil}

Annual production of milk in India is 150 million tons per year. Thousands of large dairies are engaged in handling this milk across the country. Raw chilled milk of cows and buffalos are standardized into market milk and milk products such as Butter, Ghee, Cream, Peda, Panner, Cheese, Yoghurt, Ice cream and other products. Large dairies are handling number of equipments for processing, handling, storage, packing and transportation of milk and milk products. Enormous quantities of water are used for housekeeping, sterilizing and washing equipments, during this process residual butter and related fat which are washed and get collected in effluent treatment plant as a scum. Scum is a less dense floating solid mass usually formed by a mixture fat, lipids, proteins, packing materials etc. A large dairy, which processes 5 lakh liters of milk per day, will produce approximately 200-350 kgs of effluent scum per day, which makes it difficult to dispose. Most of the dairies dispose this scum in solid waste disposal site or by incinerating. By doing so, it is economically wasteful and generates pollutants. Further, scum causes direct as well as indirect operational difficulties for effluent treatment.

\subsection{Karanja oil}

Karanja belongs to the family Leguminaceae. It is a medium sized glabrous tree that generally attains a height of about $18 \mathrm{~m}$ and a truck diam>50 $\mathrm{cm}$. It can grow under a wide range of agroclimatic condition and is a common sight around coastal areas, riverbanks tidal forests and roadsides. Karanja is a native to humid and subtropical environments having annual rainfall between $500-2500 \mathrm{~mm}$ in its natural habitat, the maximum temperature ranges from $27-38^{\circ} \mathrm{C}$ and the minimum $1-16^{\circ} \mathrm{C}$. It can grow on most soil types ranging from stony to sandy to clayey, including verticals. It does not do well in dry sands. It is highly tolerant of salinity and can be propagated either by seeds or by root suckers [7]. 
The tree bears green pods, which after 10 to 11 months gets matured and changes to a tan colour in the month of May-June. The pods are flat to elliptic 5-7 cm long and contain one to two kidney shaped brownish red kernels. The dried parts usually split with a hammer and the kernels are obtained. The oil is extracted from kernels in small oil mills are village ghanis. The yield of kernals per tree is between $8-24 \mathrm{~kg}$.

The fresh extracted oil is yellowish orange to brown and rapidly darkness on storage. It has a disagreeable odour and bitter taste. The oil contains several furanoflavones such as, karanjan, pongapin, kanjone and pongaglabrin. Karanja oil is mainly used as a raw material for soap but the main constraints for its more usage are the colour and odour[8]. The oil is used as lubricant water paint binder, and also a fuel for cooking and lamps in rural areas of India.

There are four common methods for the production of biodiesel, which are studied extensively. They are direct use and blending, micro emulsification, pyrolysis and transesterification [9]. Transesterification is the most commonly used and well established process to improve the fuel property of oils and this is the method of choice for the current study. Transesterification is a well-known process since; in 1864, Rochleder described glycerol preparation through the ethanolysis of castor oil [10], the proportion of reagents affects the process, in terms of conversion efficiency [11], and this factor differs according to the oil. Several researchers have identified the most important variables that influence the transesterification reaction, namely, the reaction temperature, the type and amount of catalyst, the ratio of alcohol to oil, the stirring rate and the reaction time, etc. [12]. In this sense, it is important to characterize the oil and the feasibility to convert the oil into biodiesel $[13,14]$

Transesterification is the displacement of alcohol from an ester by another alcohol [15]. Overall transesterification reaction was given by three consecutive and reversible reactions are believed to occur [16, 17]. This reaction is widely used to reduce the viscosity of triglycerides derived from renewable feedstock such as vegetable oil and animal fat for use in compression engine [18]. Catalyst is used to increase the transesterification reaction rate and yield. Excess alcohol used too, make possible to complete the reversible reaction [19]. When compared to other alcohols, methanol is preferred because of its low cost and its physical and chemical advantages (polar and shortest chain). It can quickly react with Triglycerides. Alkali catalyst such as Potassium Hydroxide $(\mathrm{KOH})$ is easily get dissolved in methanol. In methanolysis, formations of emulsion were quick and easily break down to form glycerol rich bottom layer and Methyl ester rich upper layer [11]. Transesterification occurs approximately 4000 times faster in the presence of alkaline catalyst than the same amount of acid catalyst [10]. For alkali catalyst transesterification, the reactant must be anhydrous, large water makes the reaction partially change to saponification [20]. $\mathrm{KOH}$ is used as an alkali catalyst because it is used widely in large industrial scale biodiesel production. However the optimum conditions for biodiesel production strongly depend upon the properties of raw oil used [21]. The chemical properties of the esters determine their feasibility as fuel, the intent of this work is to investigate and optimize the parameters involved in the transesterification of Dairy Waste Scum Oil for fuel use, to develop low cost chemical process and to determine the influence of the chemical properties of the oil in the transesterification. Transesterification tests were conducted in the stirred tank reactor that was equipped with temperature controller and a reflux condenser, to avoid methanol losses.

\subsection{Materials}

\section{Materials and methods}

\section{a). Scum oil}

This scum is collected from the scum removing area of the effluent treatment plant in a fresh condition and processed immediately to avoid increase in free fatty acid further by biological action. Scum is turbid white in color and semi solid in texture. A known quantity of scum is heated to the temperature of 50 to $60^{\circ} \mathrm{C}$ to melt into liquid condition and allowed to settle for few minutes and lower aqueous phase has to be removed further. The top oil layer is separated, centrifuged to remove the unwanted suspended solids such as film wastes and other solid wastes. It is heated to the temperature of $110^{\circ} \mathrm{C}$ until the oil becomes substantially anhydrous for transesterification [20]. It is then filtered through steel micromesh. Now the oil is ready for transesterification. Oil yield per $\mathrm{kg}$ of scum is $600 \mathrm{~g}$ with a Standard Deviation of $100 \mathrm{~g}$.

\section{b). Karanja oil}

The Biofuel plant collected Karanja seeds from formers. In the Decorticator shell was removed from the seeds, after this process oil is extracted using expeller. The cake of the seed is to be used as fertilizer. The oil collected will be stored in the Biofuel plant.

Both the oils have to be mixed in same ratio $(1: 1)$ which is called mixed oil. The other materials used in the study were $\mathrm{KOH}$ and Methanol (99.0\% pure). All the chemicals were purchased from Nice which were of analytical reagent grade. Diesel was taken from commercial diesel No. 2. 
Optimization of Biodiesel production from mixed oil (Karanja \& Dairy waste Scum oil) using

\subsection{Characterization of Mixed oil}

The fatty acid composition of the mixed oil was analyzed using gas chromatography (GC). The chromatograph consists of AGILENT 6890N equipped with flame ionization detector. Hydrogen was used as carrier gas at flow rate of $23 \mathrm{ml} / \mathrm{min}$. Column was packed with DBwax $30 \mathrm{~mm} \times 0.25 \mathrm{~mm}$. Injector port and detector port temperatures were maintained at $270 \square \mathrm{C}$ and $280 \square \mathrm{C}$ respectively. The data is given in table1.

\subsection{Transesterification reaction set up}

The transesterification reaction was carried out in a system consists of a $1 \mathrm{~L}$ double necked round bottom flask, which was put inside the heat jacket. Thermostat was a part of heat jacket to maintain the temperature of the reactant at a desired value. The reaction was carried at desirable temperature. Methanol has a boiling point of $65^{\circ} \mathrm{C}$, which vaporizes at elevated temperature during the reaction. To prevent the loss of methanol during reaction, a water-cooled condenser was used to condense the vapours and reflux it back into the reactor. The condenser also helps in maintaining atmospheric pressure inside the reactor. The side neck was used for fixing condenser. In order to achieve perfect contact between the reagents and the oil during transesterification, they must be stirred well at constant rate. A stirrer assembly was inserted through the main neck to the round bottom flask for effective stirring through a gas seal.

\subsection{Transesterification process}

The methanolysis transesterification reaction is represented in below equation.

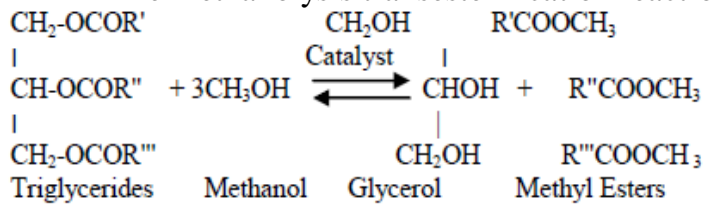

The reactor was charged with a given amount of mixed oil, which was stirred and preheated at different temperatures, mean while a solution of $\mathrm{KOH}$ in methanol $\left(\mathrm{CH}_{3} \mathrm{OH}\right)$ was added. The reaction condition was varied to obtain a large range of methyl ester yields. Heating and stirring was then stopped and the product was allowed to separate into two phases. The optimum of each parameter involved in the process was determined while the rest of them remained constant. After each optimum was obtained, this value was considered to be constant during the optimization of the next parameter. Ester yield results (given as percentages) were related to the weight of oil at the start. (Weight of ester/Weight of oil).

\subsection{Separation}

After completion of the reaction the product is transferred into a separating funnel for certain time interval (approximately $12 \mathrm{~h}$ ) for phase separation. Since the solubility of methyl ester is low, the glycerine tends to collect at the bottom. With excess alcohol the unconverted triglycerides should be essentially zero. However some monoglycerides and diglycerides must be present [21]. Due to their polarity partially reacted glycerides should be preferentially attracted to the glycerine phase and then removed when phase is separated.

Table.1Chemical composition of mixed oil.

\begin{tabular}{|l|c|c|}
\hline Component & Carbons & Fatty acid\% \\
\hline Caprylic acid & $08: 0$ & 0.33 \\
\hline Capric acid & $10: 0$ & 1.20 \\
\hline Lauric acid & $12: 0$ & 1.93 \\
\hline Myristic acid & $14: 0$ & 7.76 \\
\hline Palmitic acid & $16: 0$ & 28.93 \\
\hline Stearic acid & $18: 0$ & 10.92 \\
\hline Behenic acid & $22: 0$ & 4.08 \\
\hline Oleic acid & $18: 1$ & 31.85 \\
\hline Linoleic acid & $18: 2$ & 7.62 \\
\hline Linolenic acid & $18: 3$ & 1.44 \\
\hline Arachidonic acid & $20: 4$ & 0.92 \\
\hline
\end{tabular}

\subsection{Washing}

Washing is a process to remove the entrained glycerol, catalyst, soaps and excess methanol. Free glycerine in the product is from transesterification reaction, when esters are completely washed with water and there should be a trace amount of methanol left since the alcohol is more soluble in water than in biodiesel. The washing process also removes soaps and residual catalyst. The mixing of ester with water should be gentle to 
reduce the loss of ester due to formation of emulsion that could increase separation time [22]. To reduce the number of washing cycles the initial washing was done by diluted acetic acid continued by distilled water until the lower layer had a $\mathrm{pH}$ of similar to the $\mathrm{pH}$ of distilled water indicating the biodiesel is free from catalyst [11].

\subsection{Drying}

Water in fuel causes generally two problems; first it can cause corrosion of engine fuel systems. The other major problem contributes microbial growth [23]. Drying suggest the possible separation of water from biodiesel. Washing with water increases the water content on biodiesel. Drying helps to remove dispersed and dissolved water in biodiesel, which cause poor combustion plugging and smoke in optimal engine performance [24]. Drying was performed in hot air oven at $105^{\circ} \mathrm{C}$ as long as the water con-tent reduces below $0.05 \%$ as per ASTM. The drying process also re-moves the traces of methanol as well.

\subsection{Oil properties}

\section{Result and discussion}

The fatty acid composition of mixed oil has been reported in Table 1 . A total of $96.98 \%$ of fatty acids were identified in mixed Oil. It comprises of $55.15 \%$ Saturated fatty acids and $41.83 \%$ Unsaturated fatty acids. The maximum composition is Olieic acid $(31.85 \%)$, which is an unsaturated fatty acid.

\subsection{Catalyst optimization}

The amount of alkali catalyst $\mathrm{KOH}$ used affects the conversion efficiency of the process. The catalyst amount is varied in the range of $0.4-1.4 \mathrm{wt} . \%$ for six different values $(0.4,0.6,0.8,1.0,1.2$ and $1.4 \mathrm{wt} . \% \mathrm{KOH})$. The effect of the catalyst amount on the yield is shown in Fig. 1. It is noted that during the present experiments, the excess addition of $\mathrm{KOH}$ increased the yield. The Optimum was achieved using $1.0 \mathrm{wt} \% \mathrm{of} \mathrm{KOH}$, which produced an $89.0 \%$ yield of transparent ester. $\mathrm{KOH}$ amounts greater than $1.0 \mathrm{wt} \%$ produced a smaller ester yield, because of the presence of soaps, which prevents ester layer separation [13,25]. Optimum concentration of $\mathrm{KOH}$ was $1.0 \mathrm{wt} \%$ for $89.0 \%$ yield. It can be concluded that the concentration of $\mathrm{KOH}$ strongly dependent on the type of oils used.

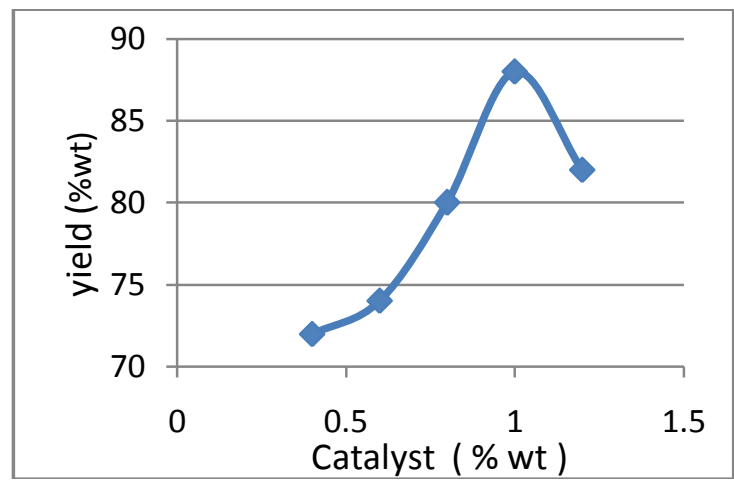

Fig.1. Percentage yield of ester vs. KOH wt.\%.

\subsection{Reaction temperature optimization}

With increase in temperature the conversion takes place at a faster rate. The effect of the temperature on the yield is shown in Fig. 2. The optimum temperature for the reaction is found to be in the range of $70^{\circ} \mathrm{C}$. Maximum yield of $94.0 \%$ esters occurred at this temperature $70^{\circ} \mathrm{C}$. This result clearly shows that the rate of the reaction was strongly influenced by temperature $[19,26]$. However there was a slight decrease in yield after $70^{\circ} \mathrm{C}$ due to the enhancement of transesterification and Saponification reaction [25]. The requirement of higher temperature in yield was due to difference in raw feed stock oil [19]. 


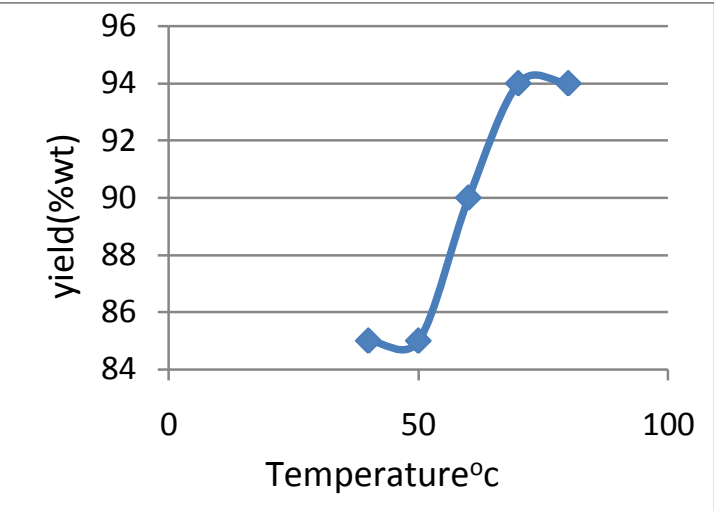

Fig.2. Percentage yield of ester vs. Temperature

\subsection{Reaction time optimization}

It has been observed that the ester yield increases with the in-crease in reaction time. The effect of the time on the yield is shown in Fig. 3. The dependency of reaction time was studied at different time intervals ranging from 20-70 min. Results obtained from the present experiments with oil revealed that about 30 min of reaction are sufficient for the completion of the transesterification. The maximum yield of $94.0 \%$ occurs at 30 $\min$. The increase in reaction temperature speeds up the reaction rate and shortens the reaction time as reported in Antonlin et al. [26].

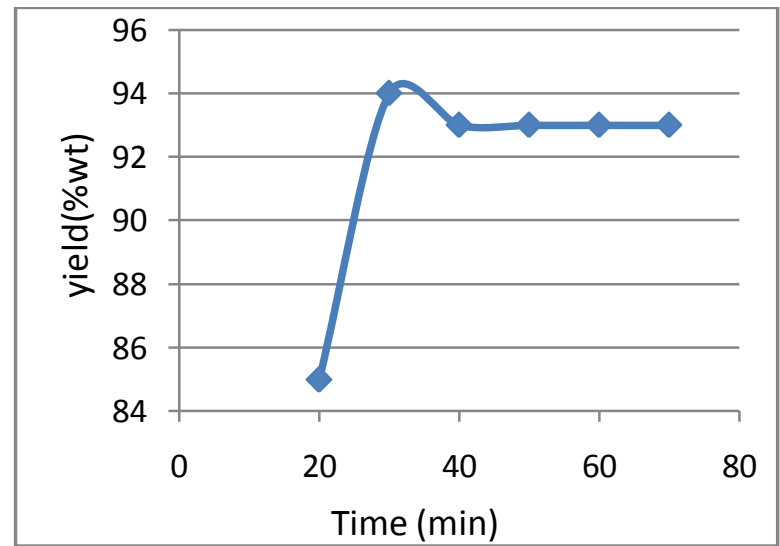

Fig.3. Percentage yield of ester vs. Time

\subsection{Alcohol optimization}

The molar ratio of alcohol to scum oil is one of the important factors that affect the conversion efficiency as well as production cost of biodiesel. The conversion efficiency is defined as the yield of the process represented in terms of weight percentage. Molar ratio is the ratio of number of moles of alcohol to number of moles of glycerides in the oil. Theoretically, transesterification reaction requires three moles of alcohol for each mole of oil. However, in practice the molar ratio should be higher than that of stochiometric ratio in order to drive the reaction towards completion [27]. The effect of molar ratio on yield is shown in Fig. 4. The methanol of about $25-150 \%$ excess was studied. The maximum conversion efficiency is achieved at the molar ratio of $6: 1$. The methyl ester yield achieved in $40 \mathrm{~min}$ is $94.0 \%$ when the methanol was $100 \%$ excess (6:1, Methanol:Oil). Also Freed man and Ramadhas [16,28] observed the optimum yield at the same $100 \%$ excess in soybean oil and rubber seed oil. 


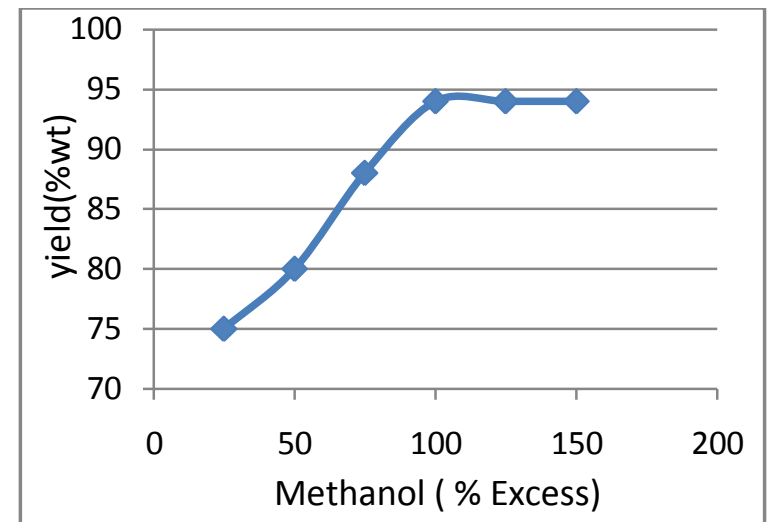

Fig.4. Percentage yield of ester vs. Methanol (\% Excess )

\subsection{Stirring optimization}

Stirring is very important in the transesterification reaction [29], as oils or fats are immiscible with $\mathrm{KOH}$-methanol solution. Once the two phases are mixed and the reaction is started stirring is no longer required. The effect of stirring on yield is shown in Fig. 5 . Methanolysis is conducted with different rate of stirring such as $150,200,250,300,350,400$ and $450 \mathrm{rpm}$. The reaction is incomplete at the rate of 200-300 rpm and rate of mixing was insignificant for methanolysis. The yield of biodiesel at 400 and $450 \mathrm{rpm}$ was same after $40 \mathrm{~min}$ i.e. $95.1 \%$. The optimum of $400 \mathrm{rpm}$ is suggested. Reaction time is the controlling factor for determining the yield of methyl esters. This suggests that the stirring speed investigated exceeds the threshold requirement on mixing [30,31].

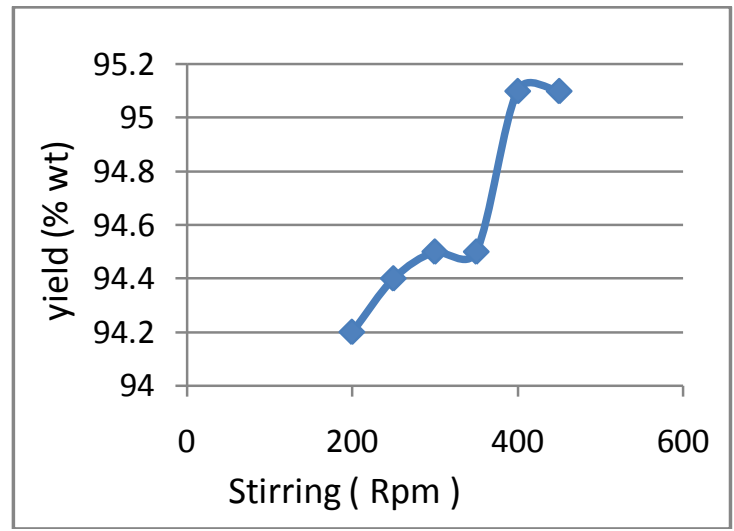

Fig. 5. Percentage yield of ester vs. Stirring

3.7. Comparison of mixed oil biodiesel (MOBD) properties with karanja oil biodiesel (KOBD) and scum oil biodiesel (SOBD).

Table 2

\begin{tabular}{|l|c|c|c|c|}
\hline Properties & $\begin{array}{c}\text { KOB } \\
\mathrm{D}^{*}\end{array}$ & $\begin{array}{c}\text { MOB } \\
\mathrm{D}^{*}\end{array}$ & $\begin{array}{c}\text { SOBD } \\
{ }^{*}\end{array}$ & Protocol \\
\hline $\begin{array}{l}\text { Viscosity@4 } \\
0^{0} \mathrm{C}(\text { cst.) }\end{array}$ & 5.6 & 4.1 & 3.7 & $\begin{array}{c}\text { ASTM } \\
\text { D445 }\end{array}$ \\
\hline $\begin{array}{l}\text { Specific } \\
\text { Gravity }\end{array}$ & 0.89 & 0.88 & 0.87 & $\begin{array}{c}\text { ASTM } \\
6751\end{array}$ \\
\hline $\begin{array}{l}\text { Flash } \\
\text { point }\left({ }^{\circ} \mathrm{C}\right)\end{array}$ & 170 & 154 & 130 & IS:1448 \\
\hline $\begin{array}{l}\text { Cloud } \\
\text { point }\left({ }^{\circ} \mathrm{C}\right)\end{array}$ & 8 & 7 & 4 & $\begin{array}{l}\text { IS:1448(P } \\
10)\end{array}$ \\
\hline $\begin{array}{l}\text { Calorific } \\
\text { value(kJ/Kg) }\end{array}$ & $\begin{array}{c}40059 . \\
\text { alil }\end{array}$ & $\begin{array}{c}41675 . \\
4\end{array}$ & $\begin{array}{c}44321 . \\
5\end{array}$ & $\begin{array}{l}\text { IS:1448(P } \\
6)\end{array}$ \\
\hline $\begin{array}{l}\text { Ash } \\
\text { content(\%w/ } \\
\text { w) }\end{array}$ & Nil & Nil & $\begin{array}{l}\text { IS:1448(P } \\
4)\end{array}$ \\
\hline $\begin{array}{l}\text { Carbon } \\
\text { content(\%w/ } \\
\text { w) }\end{array}$ & Nil & Nil & Nil & $\begin{array}{l}\text { IS:1448(P } \\
8)\end{array}$ \\
\hline
\end{tabular}




\section{Conclusion}

$>$ Biodiesel has become more alternative recently because of its environmental benefits and the fact that it is made from renewable resources.

$>$ Viscosity of the mixed oil biodiesel is low compared to the karanja oil biodiesel.

$>$ The flash point of the mixed oil biodiesel increases compared to scum oil biodiesel.

$>$ In mixed oil biodiesel there is no settling of segments.

$>$ In mixed oil biodiesel the yield is more compared to individual other oils.

$>$ There are two aspects of cost of biodiesel, the costs of raw material (Fat \& Oil) and cost of processing.

$>$ In terms of production cost, there are also two aspects, the transesterification process and by product (Glycerol) recovery.

$>$ The cost of the mixed biodiesel is very competitive 60-70\% less when compared to other biodiesel produced from edible and non edible fat and oils.

$>$ Under optimal conditions, mixed oil methyl esters yield of $95.1 \%$, was achieved.

\section{References}

[1] Duke J A, Handbook of every crops. (Unpublished data) http://www.hotr.purdue.edu/duke_energy/pongamia_pinnata.htm,1983

[2] Bringi N V, Non-tradional oil seeds and oils of India (Oxford and IBH publishing co.pvt,New delhi)1987 pp143-166.

[3] Altun S. Fuel properties of biodiesels produced from different feedstocks. Energy Educ Sci Technol Part A 2011;26(2):165-74.

[4] Kalam MA, Saifullah MG, Masjuki HH, Husnawan M, Mahlia TMI. PAH and other emissions from coconut oil blended fuels. J Sci Ind Res 2008;67(11):1031-5

[5] Van Gerpen JH, Hammond EG, Yu L, Monyem A. Determining the influence of contaminants on biodiesel properties. Society of Automotive Engineers Technical Paper Series, SAE, Warrendale, PA. 1997;Paper No-971685.

[6] Demirbas AH. Inexpensive oil and fats feedstocks for production of biodiesel. Energy Educ Sci Technol Part A 2009;23(1):1-13.

[9] Ramadhas AS, Jayaraj S, Muraleedharan C. Use of vegetable oil as I.C engine fuels a review. Renew Energy 2004;29(5):727-42.

[10] Formo MW. Ester reactions of fatty materials. J Am Oil Chem Soc 1954;31(11):54859.

[11] Freedman B, Pryde EH, Mounts TL. Variables affecting the yields of fatty esters from transesterified vegetable oils. J Am oil Chem Soc 1984;61(10):1638-43.

[12] Peterson CL, Reece DL, Cruz R, Thompson J. A comparison of ethyl and methyl esters of vegetable oil as diesel fuel substitute. Liquid fuels from renewable resources. In: Proceedings of alternative energy conference of ASAE, 1992. p.99-110.

[13] Coteron A, Vicente G, Martinez M, Aracil J. Biodiesel production from vegetable oils. Influence of catalysts and operating conditions. Recent Res Dev Oil Chem 1997;1:109-14.

[14] Anggraini AA. Wiederverwertung von gebrauchten speiseolen/-fetten imenergetisch-technischen Bereich-ein Verfahren und dessen Bewertung. In: Dep. Agrartechnik,Universitat Gesamthochschule ,Kassel: Witzenhausen, Germany; 1999. p.193.

[15] Otera J. Transesterification. Chem Rev 1993;93(4):1449-70.

[16] Freedman B, Butterfield RO, Pryde EH. Transesterification kinetics of soybean oil. J Am Oil Chem Soc 1986;63(10):1375-80.

[17] Noureddini H, Zhu D. Kinetics of transesterification of soy bean oil. J Am Oil Chem Soc 1997;74(11):1457-63.

[18] Krawczyk T. Biodiesel alternative fuel makes inroads but hurdles remain. Inform 1996;7(8):800-15.

[19] Ma F, Hanna MA. Biodiesel production: a review. Bioresour Technol 1999;70(1):1-15.

[20] Wright HJ, Segur JB, Clark HV, Coburn SK, Langdon EE, DuPuis RN. A report on ester interchange. Oil and Soap $1944 ; 21(5): 145-8$

[21] Dorado MP, Ballesteros E, Lpez FJ, Mittelbach M. Optimization of alkalicatalyzed transesterification of Brassica carinata oil for biodiesel production. Energy Fuels 2004;18(1):77-83

[22] Ma F, Clements LD, Hanna MA. The effects of catalyst, free fatty acids and water on transesterification of beef tallow. Trans ASAE1998;41(5):1261-4.

[23] Sinha S, Agarwal AK, Garg S. Biodiesel development from rice bran oil: transesterification process optimization and fuel characterization. Energy Convers Manage 2008;49(5):1248-57.

[24] Demirbas A. Progress and recent trends in bio-diesel fuels. Energy Convers Manage 2009;50(1):14-34

[25] Phan AN, Phan TM. Biodiesel production from waste cooking oils. Fuel 2008;87:3490-6.

[26] Antonlin G, Tinaut FV, Briceno Y, Castano V, Perez C, Ramirez AI. Optimisation of biodiesel production by sunflower oil transesterification. Bioresour Technol 2002;83(2):111-4.

[27] Demirbas MF. Microalgae as a feedstock for biodiesel. Energy Educ Sci Technol Part A 2010;25(1):31-43.

[28] Ramadhas AS, Jayaraj S, Muraleedharan C. Biodiesel production from high FFA rubber seed oil. Fuel 2005;84(4):335-40.

[29] Sharma YC, Singh B. Development of biodiesel from Karanja, a tree found in rural India. Fuel 2008;87(8-9):1740-2.

[30] Ma F, Clements LD, Hanna MA. The effect of mixing on transesterification of beef tallow. Bioresour Technol 1999;69(3):289-93.

[31] Murugesan A, Umarani C, Chinnasamy TR, Krishnan M, Subramanian R, Neduzchezhain N. Production and analysis of bio-diesel from non-edible oils a review. Renew Sust Energy Rev 2008;13(4):825-34. 